\title{
Preparation, In-Vitro Bioactivity And Mechanical Properties of Reinforced 45S5 Bioglass Composite With $\mathrm{HA}-\mathrm{ZrO}_{2}$ Powders
}

\author{
SUNIL PRASAD ${ }^{1 *}$, VIKAS KUMAR VYAS ${ }^{1}$, KUMARI DEEPA MANI², \\ MD. ERSHAD ${ }^{1}$ and RAM PYARE ${ }^{1}$
}
${ }^{1}$ Department of Ceramic Engineering, Indian Institute of Technology (BHU), Varanasi-221005, India. Department of Zoology, Banaras Hindu University, Varanasi-221005, India.
${ }^{*}$ Corresponding author E-mail: sunilmnnit25@gmail.com

http://dx.doi.org/10.13005/ojc/330328

(Received: April 07, 2017; Accepted: May 05, 2017)

\begin{abstract}
Bioglass(45S5)-Hydroxyapatite $(\mathrm{HA})$-Zirconia $\left(\mathrm{ZrO}_{2}\right)$ biocomposites were prepared and heat treated at $1000,1100,1200^{\circ} \mathrm{C}$ for 5 hour. Simulated body fluid (SBF) is used to immersed these samples for 1,3,7,14,21 days. Samples were characterized before and after immersion in simulated body fluid by using FTIR, X-ray diffraction (XRD) and scanning electron microscope (SEM). FTIR were used to observed the formation of hydroxyapatite layer $(\mathrm{HA})$ on the surface of these bio composite samples. The $\mathrm{pH}$ of the SBF were measured by using $\mathrm{pH}$ meter at $1,3,7,14,21$ days. Different techniques were used to measured various mechanical properties and it was found to increase with increasing $\mathrm{HA}(10,20,30,40 \mathrm{wt} \%)$ and $\mathrm{ZrO}_{2}(5,10,15,20 \mathrm{wt} \%)$ content.
\end{abstract}

Keywords:Bioglass(45S5), Hydroxyapatite(HA),Zirconia, Biocomposites, Simulated body fluid (SBF), FTIR spectrometry.

\section{INTRODUCTION}

Hench glass $45 \mathrm{~S}^{1}{ }^{1}$ has been extensively used to repair hard and soft tissue bone because of their excellent bioactive properties. However, an incomplete conversion into a bone-like material undergo by these bio active materials which severely limits their use in biomedical application ${ }^{2} .45 S 5$ Bioglass is generally used in making various biomedical devices, such as middle ear, dental implants etc. Due to the brittleness nature of
$45 \mathrm{~S} 5$ bio glass and relatively its low strength, the application in non-load bearing situations is limited ${ }^{3}$. This silicate-based bio active glass has very low degradation and It has been found that remains in our body approximately more than one year after implantation ${ }^{4}$. This bioglass(45S5) does not alone provide sufficient bio activity and mechanical strength due to this reason we need to reinforced this bio active glass with increasing content of $\mathrm{HA}$ and $\mathrm{ZrO}_{2}$. 
Chemical composition of HA has similar to inorganic mineral of our bone and teeth ${ }^{5-6}$. It has excellent biocompatibility and bio activity. HA offers excellent biocompatibility, bioactivity ${ }^{7}$, low density, low compressive strength and low hardness. It has also relatively low mechanical properties. Therefore the use of HA as a load bearing implant teeth is very limited. Due to these limitation there is a need to strengthening of $\mathrm{HA}$ without loosing its biocompatibility ${ }^{8}$. It was found that zirconia $\left(\mathrm{ZrO}_{2}\right)$ possess high mechanical strength and very low toxicity ${ }^{9-10}$. For this reason $\left(\mathrm{ZrO}_{2}\right)$ is widely used as a biomaterial for hipprosthesis ${ }^{11-12}$, tooth crowns ${ }^{13}$ and dental implants ${ }^{14}$ and it was formed as a new bone restoring material in future. Sintered zirconia $\left(\mathrm{ZrO}_{2}\right)$ has very high mechanical strength than a cortical bone therefore new class zirconia is used as a new bone restoring material ${ }^{15-16}$. Because of difference in strength, the amount of stress and frequent bone fracture may occur resulting in bonding to a host bone. Due to the poor affinity to cells and tissues of zirconia $\left(\mathrm{ZrO}_{2}\right)$, there is a need to make composite by $\mathrm{HA}$ and $\mathrm{ZrO}_{2}$ mixed together in order to combine the biocompatibility of $\mathrm{HA}$, high toughness and strength of $\mathrm{ZrO}_{2}$. It has been observed zirconia retain high mechanical strength and toughness with $\mathrm{HA}$ without affecting the biocompatibility of $\mathrm{HA}^{17-21}$. The changes in physicochemical properties of the material is due to decomposition of HA. Performance of implant material is affected by change in its density, solubility, resorption and biocompatibility during implantation in a living body. Therefore HA decay is an important problem, both from scientific and application point of view. It has been found that calcium present in hydroxyapatite can react with $\mathrm{ZrO}_{2}$ transformed zirconia into cubic form which make it tough by this transformation ${ }^{22}$.

Further it was observed that HA$\mathrm{ZrO}_{2}$ composites have very improved strength and toughness as compared to monolithic HA itself ${ }^{23-26}$. It is well known that $\mathrm{P}_{2} \mathrm{O}_{5}$ act as a strong glass network former. Covalent bond is formed between $\mathrm{PO}_{4}$ tetrahedra structures in chains or rings by bridging oxygens ${ }^{27}$. It is also known that $\mathrm{Na}_{2} \mathrm{O}$ and $\mathrm{CaO}$ were act as glass network modifiers and formed non-bridging oxygens (NBO) into the glass network ${ }^{28}$. In environment $\mathrm{Zr}$ present as a common trace element or metallic $\mathrm{Zr}(\mathrm{IV})$ normally present in human bone and tissue as low in the range of $2-10 \mathrm{mg} / \mathrm{kg}$ body weight with an estimated average daily intake in humans of $\sim 2.6 \mathrm{mg}$. The toxicity of $\mathrm{Zr}$ has been assessed low to moderate in animals ${ }^{29}$.Ceramics can be devided into two main groups that has been used as an implant material i.e. bioinert and bioactive. Bioinert ceramics, such as zirconia $\left(\mathrm{ZrO}_{2}\right)$ show no interaction with the surrounding and living tissue. However, bioactive ceramics such as calcium phosphates are forming bonds with living hard and soft tissue. Since it has the main inorganic constituent of bones and teeth. HA is the most interesting bioactive ceramics ${ }^{30}$.

Partially stabilized zirconia (PSZ) is bioinert and has highest strength and fracture strength was mixed with $\mathrm{HA}$ to obtained a bioactive implants with increased mechanical properties ${ }^{31-32}$. Similarly other oxides, such as alumina $\left(\mathrm{Al}_{2} \mathrm{O}_{3}\right)^{33}$, titania $\left(\mathrm{TiO}_{2}\right)^{34}$, and yttria $\left(\mathrm{Y}_{2} \mathrm{O}_{3}\right)^{35}$ were studied to prepare $\mathrm{HA}$ composites in different structures via several methods.

In present investigation to obtained high load bearing implants of $\mathrm{BG}-\mathrm{HA}-\mathrm{ZrO}_{2}$ composites were prepared with increasing $\mathrm{HA}$ and $\mathrm{ZrO}_{2}$ in base bioactive glass to make biocomposite. Structural in-vitro and mechanical properties of

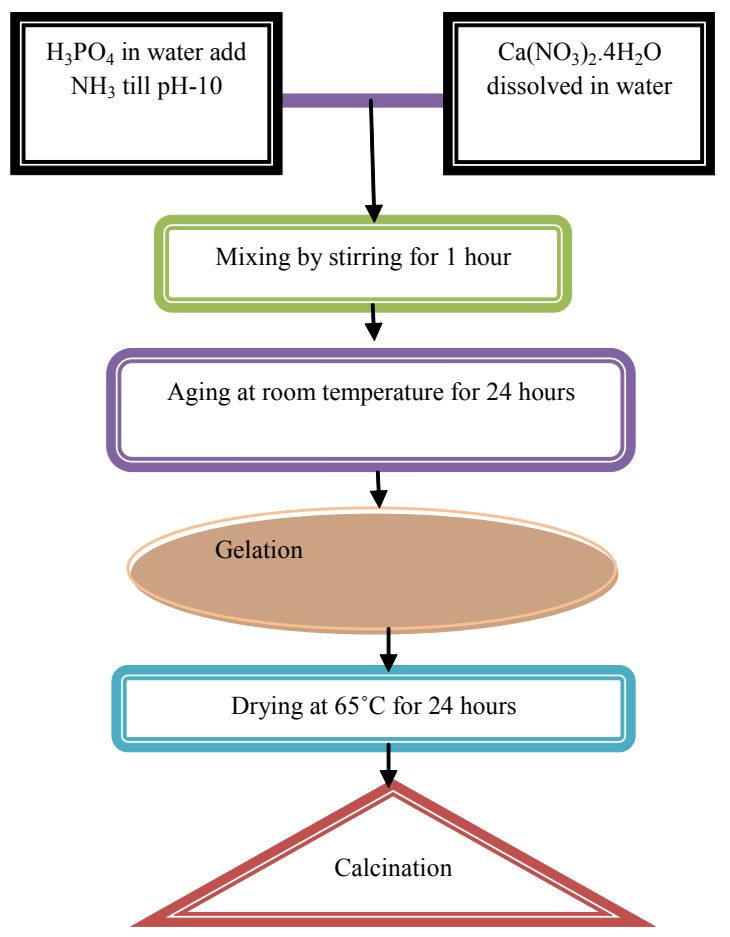

Fig.1: Flow chart of hydroxyapatite preparation by the sol-gel route 
these biocomposite material were studied at different sintering temperature.

\section{MATERIALS AND METHODS}

\section{Synthesis of BG-HA-ZrO ${ }_{2}$ composites}

4555 Bioglass was prepared by using analytical grade quartz, calcium carbonate, sodium carbonate and ammonium dihydrogen orthophosphate by melting at $1400-1410^{\circ} \mathrm{C}$ with air as atmosphere and annealed in air oven at $500-550^{\circ} \mathrm{C}$. Hydroxyapatite was prepared by solgel technique Fig.1. Bioglass (45S5), $\mathrm{HA}$ and $\mathrm{ZrO}_{2}$ powder were milled and mixed by ball milling about 4 hours. Samples were placed and sintered in furnace at 1000,1100 and $1200^{\circ} \mathrm{C}$ for 5 hours, rate of heating and cooling is at $5^{\circ} \mathrm{C} /$ minute. Uniaxial pressure of $100 \mathrm{MPa}$ was applied to form rectangular bar shape sample of $4 \mathrm{~mm} \times 6 \mathrm{~mm} \times 40 \mathrm{~mm}$ size by using die of size $55 \mathrm{~mm} \times 10 \mathrm{~mm}$. The composition of bioglass and biocomposites were illustrated in Table 1.

\section{XRD Characterization}

$\mathrm{Cu}-\mathrm{K} \alpha$ radiation at $40 \mathrm{kV} / 40 \mathrm{~mA}$ was used to evaluate the presence of different phases through X-raydiffraction(XRD,BrukerD8)analysis. The scanning range of $2 \theta$ angle was from $20^{\circ}$ to $70^{\circ}$ at scanning rate of $0.03809^{\circ} / \mathrm{s}$ with step size of $0.02^{\circ}$. The diffractograms were compared with JCPDS cards.

\section{In-vitro analysis of biocomposites samples}

At $37^{\circ} \mathrm{C}$, the in vitro bioactivity evaluation of the biocomposite were determined by sample immersion in simulated body fluid (SBF) solutions for 1 to 21 days. SBF were prepared to determine in-vitro analysis of biocomposite samples. The SBF solution was prepared by Kokubo method ${ }^{36}$ and compared ion concentration (mM/litre) of SBF with human blood plasma solution which are shown in table 2.The composite samples in the form of circular pellet having the size of $1 \mathrm{~cm}$ diameter were immersed in SBF at $37^{\circ} \mathrm{C}$. $\mathrm{pH}$ of the SBF solutions was measured by using digital $\mathrm{pH}$ meter (model-1611,ESICO-USA) for $1,3,7,14,21$ days time periods.

\section{Structural analysis of biocomposites by FTIR transmittance spectroscopy}

Immersion of biocomposites in SBF before and after, formation of hydroxy carbonated apatite layer was formed on the surface and determined by FTIR(Shimadzu-8400S,Japan)used to record at the room temperature in the spectral range $4000-400 \mathrm{~cm}^{-1}$.

\section{Morphological analysis using scanning electron microscope (SEM) and EDS}

The surfaces of bioactive composite were analyzed before and after immersion in SBF. These biocomposite samples were coated with gold plate before scanning of the sample with SEM. A scanning electron microscope (SEM-EV018,CarlZeiss,UK) was used to analysis the surface microstructure of these samples before and after immersion in SBF. Elemental analysis were carried out by using energy dispersion spectrometry (EDS-51N1000,Oxford,UK) ${ }^{37-41}$.

\section{Physical and mechanical properties}

Archimedes Principle was used to determine the density (Sartorius, Model: BP221S,USA) of these samples. UTM Machine (TiniusOlsen,H10KL, India) have been used to determine Compressive and toughness strength. Vickers micro hardness test was calculated using a micro hardness tester (HMV-2, Shimadzu, Japan) with a diamond

Table 1: Composition of Bioactive Glass and Biocomposites (BHZ1, BHZ2, BHZ3, BHZ4)

\begin{tabular}{|c|c|c|c|}
\hline \multicolumn{4}{|c|}{ Composition (wt \%) } \\
\hline $\begin{array}{l}\text { BG (45S5) } \\
\text { Biocomposite Samples }\end{array}$ & $\begin{array}{r}45 \mathrm{SiO}_{2} \\
\mathrm{BG}(45 \mathrm{~S} 5)\end{array}$ & $\begin{array}{c}24.5 \mathrm{Na}_{2} \mathrm{O} \\
\text { HA }\end{array}$ & $\begin{array}{l}6 \mathrm{P}_{2} \mathrm{O}_{5} \\
\mathrm{ZrO}_{2}\end{array}$ \\
\hline $\mathrm{BHZ1}$ & 85 & 10 & 5 \\
\hline $\mathrm{BHZ2}$ & 70 & 20 & 10 \\
\hline $\mathrm{BHZ3}$ & 55 & 30 & 15 \\
\hline $\mathrm{BHZ4}$ & 40 & 40 & 20 \\
\hline
\end{tabular}


indenter at $1.968 \mathrm{~N}$ load for 30 s. The average micro hardness was calculated by using formula. $\mathrm{HV}=0.001854 \mathrm{P} / \mathrm{d} 2$

\section{RESULT}

\section{XRD analysis of bioactive composite sample.}

The XRD pattern of sample $\mathrm{BHZ1}$, BHZ2, $\mathrm{BHZ3}$ and $\mathrm{BHZ4}$ were presented in Fig.2, heated at $1000^{\circ} \mathrm{C}$ contained hydroxyapatite and tetragonalzirconia phases. Upon heat treatment at higher temperatures i.e. $1100^{\circ} \mathrm{C}$ and $1200^{\circ} \mathrm{C}$, the zirconia and wollastonite gradually transformed into zirconium silicate (zircon) respectively. Before and after soaking in SBF for various time periods i.e.1, 3, 7, 14 and 21 days, typical XRD patterns were obtained on the surfaces of biocomposites. XRD patterns of the biocomposite sample with $\mathrm{HA}(10,20,30,40 \mathrm{wt} \%)$ and $\mathrm{ZrO} 2(5,10,15,20 \mathrm{wt} \%)$ is shown in the Fig.2(a-d). After immersion in SBF, crystalline peaks appear in the XRD patterns which indicates the formation of a crystalline layer on the surface of the bio composites. Initially well-defined hydroxyapatite $(\mathrm{HA})$ peaks develop at $(2 \theta)$ values of $23-27^{\circ}$ of these composites after 3 days of soaking in SBF and $\mathrm{ZrO}_{2}$ peaks develop at $(2 \theta)$ values of $30-35^{\circ}$ after 7 days of immersion.

The reaction between the $\mathrm{HA}$ and the $\mathrm{ZrO}_{2}$ forms TCP and cubic $\mathrm{ZrO}_{2}$ as follows ${ }^{42}$ :

$$
\mathrm{Ca}_{10}\left(\mathrm{PO}_{4}\right)_{6}(\mathrm{OH})_{2} \rightarrow 3 \mathrm{Ca}_{3} \mathrm{P}_{2} \mathrm{O}_{8}+\mathrm{CaO}+\mathrm{H}_{2} \mathrm{O}
$$

$\mathrm{CaO}+\mathrm{ZrO}_{2} \rightarrow$ Cubic-ZrO ${ }_{2}$ or $\mathrm{CaZrO}_{3}\left(\mathrm{~T} \geq 1200^{\circ} \mathrm{C}\right) \ldots$

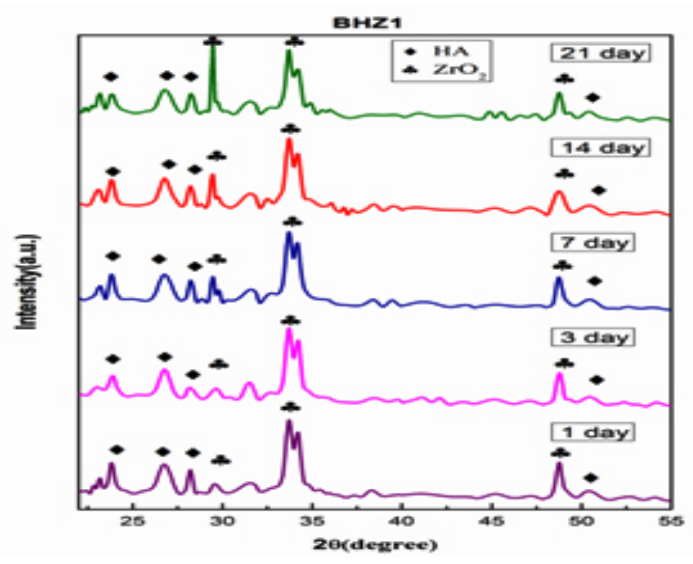

(a)

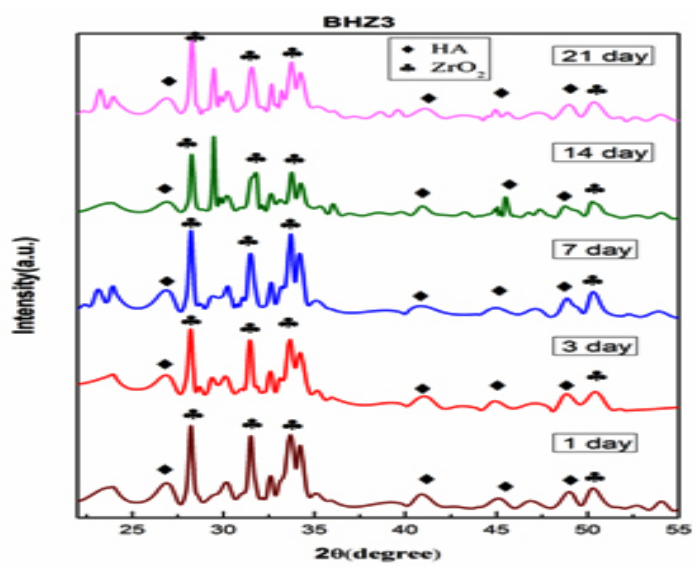

(c)

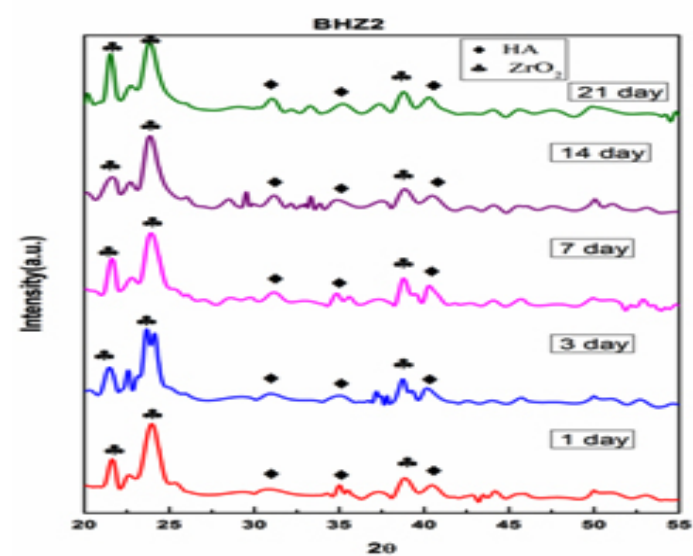

(b)

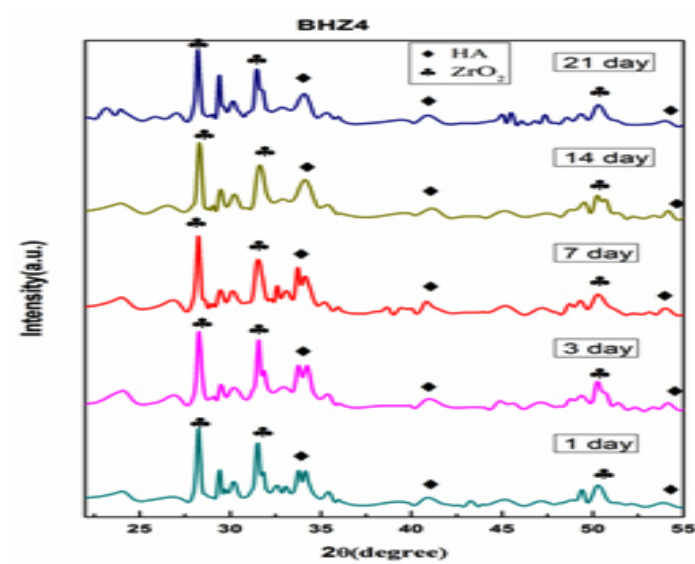

(d)

Fig. 2: (a,b,c,d) XRD pattern of biocomposite sample BHZ1, BHZ2, BHZ3 and BHZ4 after SBF treatment $(1,3,7,14,21)$ days 
Table 2: The ions concentration of SBF solution and human blood plasma ( $\mathrm{mM} /$ /itre)

\begin{tabular}{lrrr}
\hline S.No. & Ion & $\begin{array}{r}\text { Simulated } \\
\text { body } \\
\text { fluid } \\
\text { solution }\end{array}$ & $\begin{array}{r}\text { Human } \\
\text { blood } \\
\text { plasma }\end{array}$ \\
\hline & $\mathrm{Na}^{+}$ & 142.1 & 142.1 \\
2 & $\mathrm{~K}^{+}$ & 5.2 & 5.2 \\
3 & $\mathrm{Mg}^{+}$ & 1.6 & 1.6 \\
4 & $\mathrm{Ca2}^{+}$ & 2.6 & 2.6 \\
5 & $\mathrm{Cl}^{-}$ & 147.9 & 103.1 \\
6 & $\mathrm{HCO}^{-}$ & 4.2 & 27.0 \\
7 & $\mathrm{HPO}^{-}$ & 1.1 & 1.1 \\
8 & $\mathrm{SO}^{-}$ & 0.6 & 0.6 \\
\hline
\end{tabular}

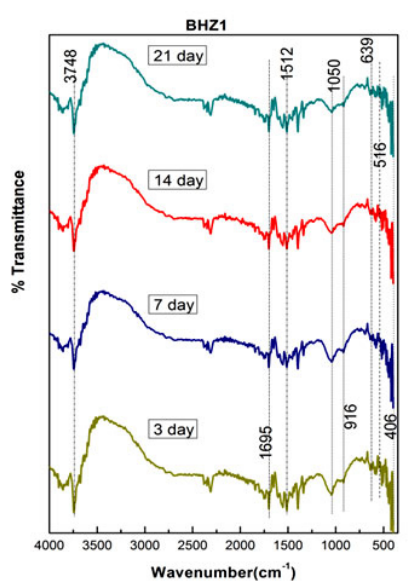

(a)

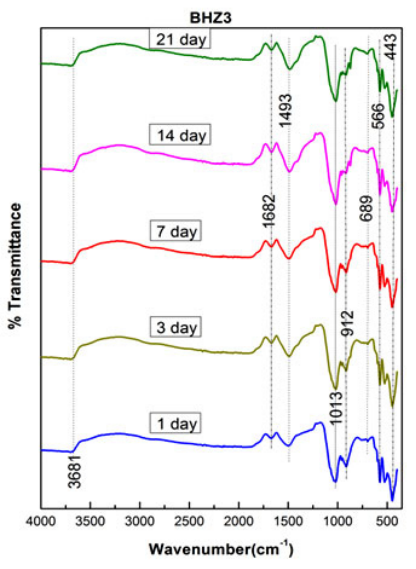

(c)
Hydroxyapatite transforms into TCP by releasing calcium (or $\mathrm{CaO}$ ) and water vapour as shown in equation (1). HA phase is not stable, and TCP is the major phase. According to reaction (2), the reaction continues, a lot of $\mathrm{CaO}$ is released, thus cubic- $\mathrm{ZrO}_{2}$ are formed.

Transmission FTIR analysis of biocomposite sample

FTIR spectra bands of $\mathrm{BHZ1}$ sample illustrated in Fig.3(a) for $3,7,14$ and 21 days treated with SBF. At 516 and $639 \mathrm{~cm}^{-1} \mathrm{P}-\mathrm{O}$ bending (crystalline) and $\mathrm{P}-\mathrm{O}$ bending (amorphous) were formed. At $916 \mathrm{~cm}^{-1} \mathrm{C}-\mathrm{O}$ stretching band shown which indicates the formation of HCA layer. The bands at about 1512 and $1695 \mathrm{~cm}^{-1}$ were related to

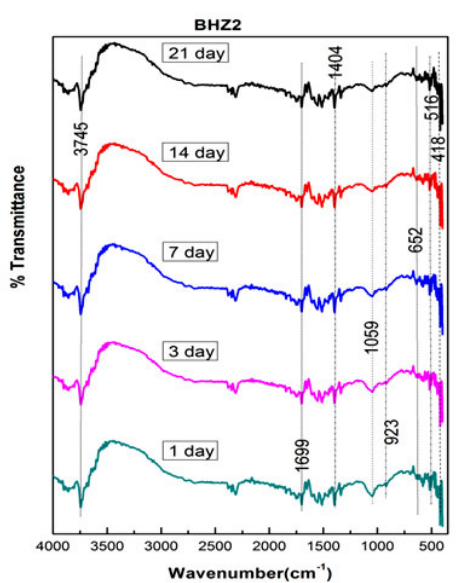

(b)

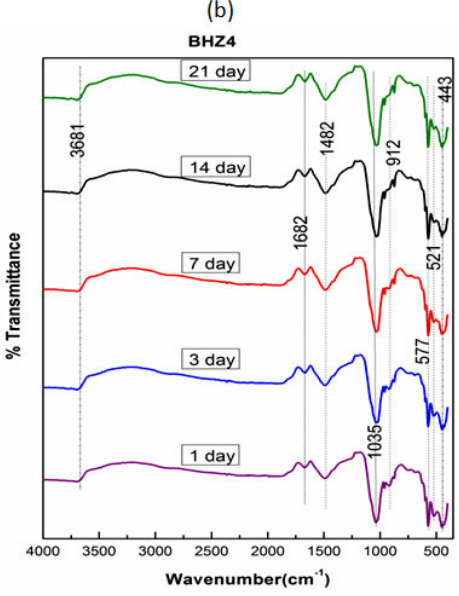

(d)

Fig.3: (a,b,c,d) FTIR of the biocomposite sample BHZ1, BHZ2, BHZ3 and BHZ4 after immersion in SBF treatment for $(1,3,7,14,21)$ days 
C-O (Stretch) and C=O (Stretch) modes respectively, and the broad band at about $3748 \mathrm{~cm}^{-1}$ are formed due to $\mathrm{O}-\mathrm{H}$ groups on the surface. The samples in SBF for prolonged period indicates the similar response with small decrease in the intensities of the bands due to the formation of HCA layer. Further almost similar vibrations in all specimens $(\mathrm{BHZ2}$, $\mathrm{BHZ3}, \mathrm{BHZ4}$ ) in Fig.3(b),(c),(d) which confirm apatite formation, these bands are also shown in table 3 .

The samples in SBF for prolonged period shows the same response with small decrease in the intensities of the bands that resulted in the formation of HCA layer.

Zr can be react in two ways.

1. $\mathrm{Zr}$ as glass network modifier: Possibility of some splitting in Si-O-Si bonds leads to lower connectivity of the silicate network with increase in $\mathrm{O} / \mathrm{Si}$ ratio in $\mathrm{BHZ}$ with respect to 45S5. This phenomenon results in decrease of bridging oxygens and with an increase in non-bridging oxygens. However, after the incorporation of $\mathrm{Zr}$, we found a significant reduction in the number of non-bridging oxygen in the FTIR spectra of the dried gels.

2. $\quad Z r$ as glass former: $Z r$ may even act as a glass former with $\left[\mathrm{ZrO}_{4}\right]^{4-}$ units occupying some positions of $\left[\mathrm{SiO}_{4}\right]^{4-}$ tetrahedra. The extent of shifting the $29 \mathrm{Si}$, resonance for a given tetrahedron is positive due to each covalent Si- O-Zr bridge ${ }^{43}$.

\section{$\mathrm{pH}$ analysis of biocomposite samples}

Change in $\mathrm{pH}$ of biocomposite(BHZ1, $\mathrm{BHZ2}, \mathrm{BHZ3}$ and $\mathrm{BHZ} 4$ ) were presented in Fig.4 after immersing all samples in SBF for different time period. It was found that $\mathrm{pH}$ has increased upto 7 days due to the fast release of alkali ions $\left(\mathrm{Na}^{+}\right)$and alkaline earth ions $\left(\mathrm{Ca}^{2}+\right)$ and its exchange with $\mathrm{H}^{+}$or $\mathrm{H}_{3} \mathrm{O}+$ ions in the simulated body fluid (SBF) solution. There is increase in $\mathrm{OH}^{-}$ions which increase the $\mathrm{pH}$ of the solution and breaking of Si-O-Si bonds which hold the glass structure together. Thus there is formation

Table 3: FTIR spectra bands of BHZ1, BHZ2,BHZ3,BHZ4 sample

\begin{tabular}{lrrrrr}
\hline Sample & $\begin{array}{r}\text { P-O } \\
\text { (crystalline) }\end{array}$ & $\begin{array}{r}\text { P-O } \\
\text { (amorphous) }\end{array}$ & $\begin{array}{r}\text { C-O } \\
\text { (Stretch) }\end{array}$ & $\begin{array}{r}\text { C=O } \\
\text { (Stretch) }\end{array}$ & $\begin{array}{r}\text { O-H } \\
\text { groups }\end{array}$ \\
\hline BHZ1 & 516 & 639 & 916,1512 & 1695 & 3748 \\
BHZ2 & 516 & 652 & 923,1404 & 1699 & 3745 \\
BHZ3 & 566 & 689 & 912,1493 & 1682 & 3681 \\
BHZ4 & 521 & 577 & 912,1482 & 1682 & 3681 \\
\hline
\end{tabular}

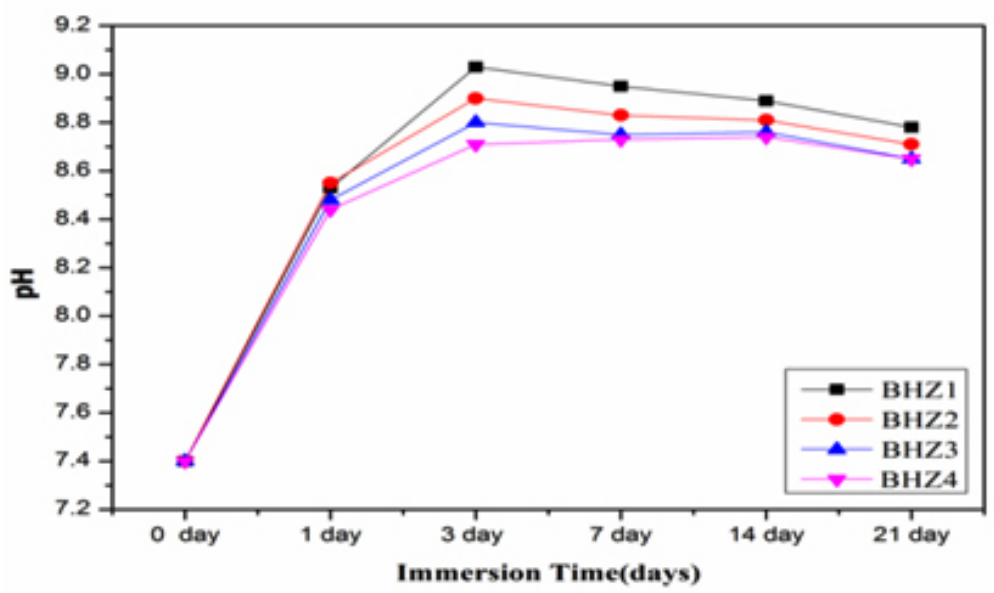

Fig. 4: $\mathrm{pH}$ behaviour of the SBF after immersion of the biocomposite samples (BHZ1, BHZ2, BHZ3, BHZ4) 
of silanols which decrease the $\mathrm{pH}$ of the solution after 7 to 21 days. Soaking in SBF leads to the formation of an apatite layer on the surface of the composite samples depends upon the morphological properties of biocomposite sample ${ }^{45-46}$. In vitro hydroxyapatite

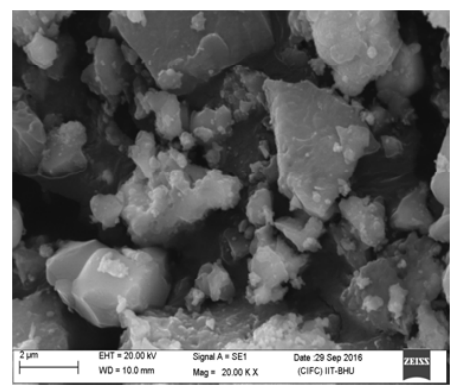

(a)

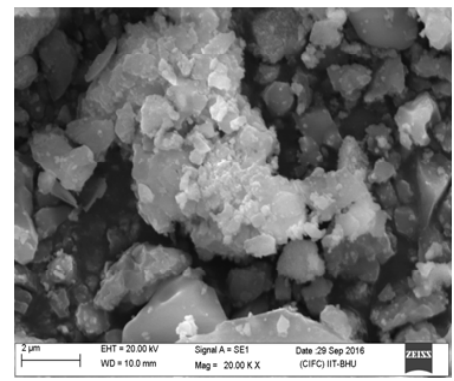

(c)

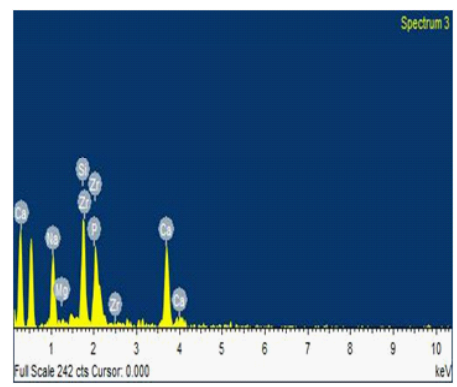

(e)

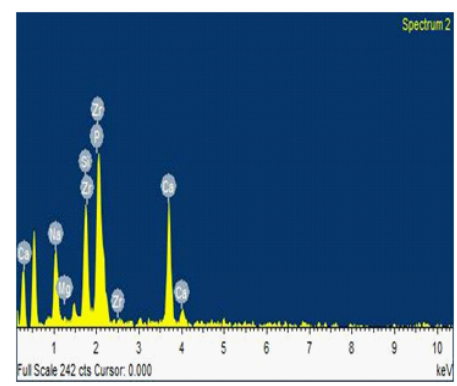

(g) formation on body fluid inside simulated body fluid $(\mathrm{SBF})^{47}$ has four proposed stages. First: Fast cation exchange of $\mathrm{Na}^{+}$and $\mathrm{Ca}^{2+}$ with $\mathrm{H}^{+}$in solution, forming silanol bonds $(\mathrm{Si}-\mathrm{OH})$ on the glass surface i.e. $\mathrm{Si}-\mathrm{O}-\mathrm{Na}^{+}+\mathrm{H}^{+}+\mathrm{OH} \rightarrow \mathrm{Si}-\mathrm{OH}+\mathrm{Na}^{+}(\mathrm{aq})+\mathrm{OH}^{-}$

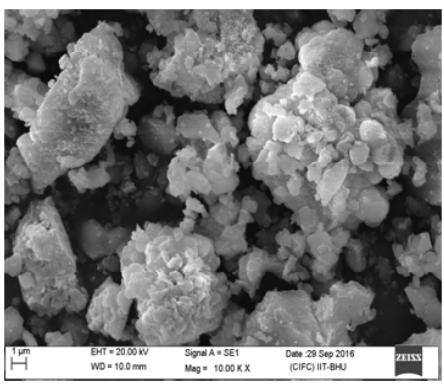

(b)

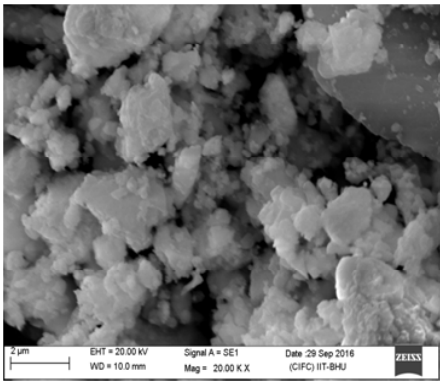

(d)

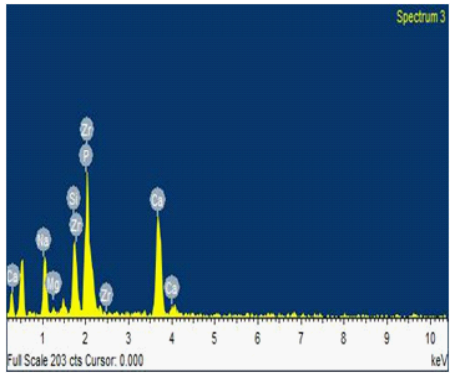

(f)

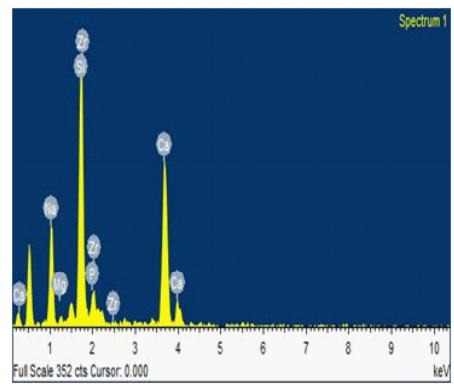

(h)

Fig.5: SEM of biocomposite samples after SBF (a-d) and EDX of biocomposite samples (e-h) 
Second: A silica-rich (cation vacant) regions forms near the glass surface results increase in $\mathrm{pH}$. Phosphate is also dissipated from the glass if available in the composition. Third: High local $\mathrm{pH}$ splits the Si-O-Si bonds and release $\mathrm{OH}^{-}$which causes an attack to the silica glass network. Soluble silica dissolves in the solution in the form of $\mathrm{Si}(\mathrm{OH})^{4}$ and leaving more $\mathrm{Si}-\mathrm{OH}$ (silanols) at the glass-solution interface: $\mathrm{Si}-\mathrm{O}-\mathrm{Si}+\mathrm{H}_{2} \mathrm{O} \rightarrow \mathrm{Si}-\mathrm{OH}+$ $\mathrm{OH}-\mathrm{Si}$, Fourth: Condensation of $\mathrm{Si}-\mathrm{OH}$ groups near the glass surface due to re polymerization of the silica-rich layer.

\section{SEM and EDS analysis of biocomposite sample} after soaking in SBF

After in vitro studies the surface morphology

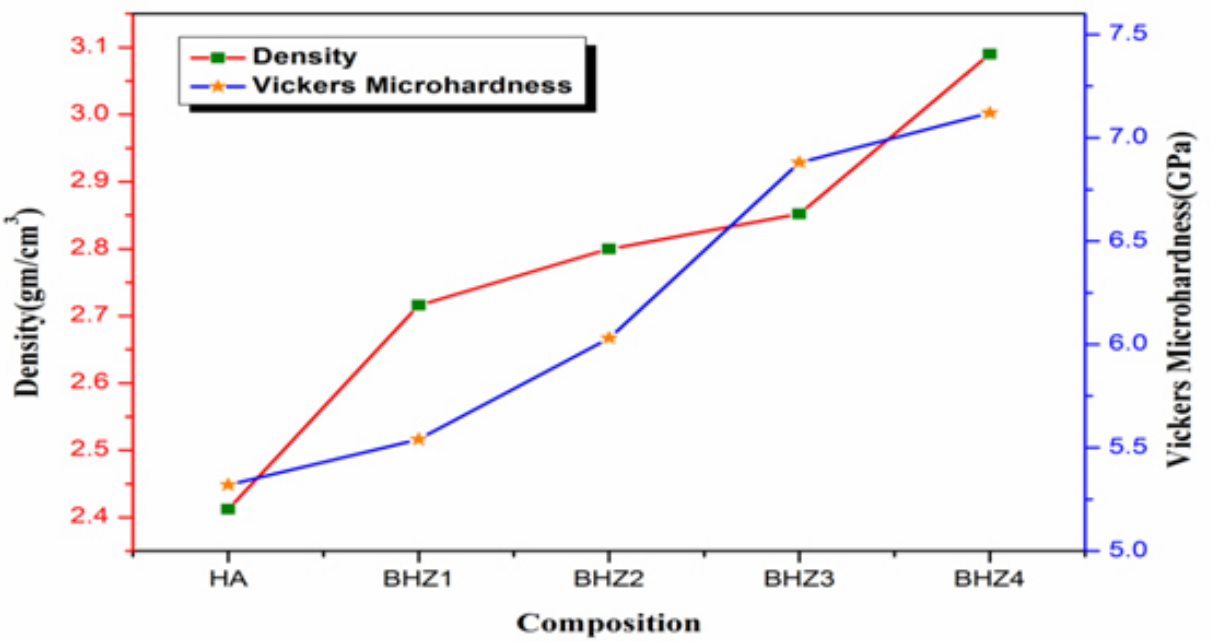

(a)

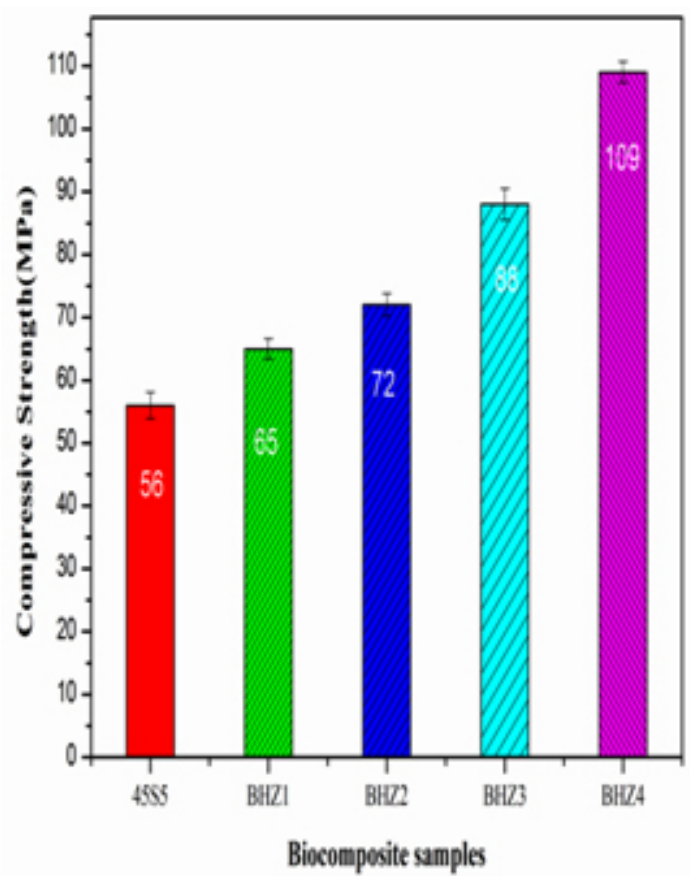

(b)

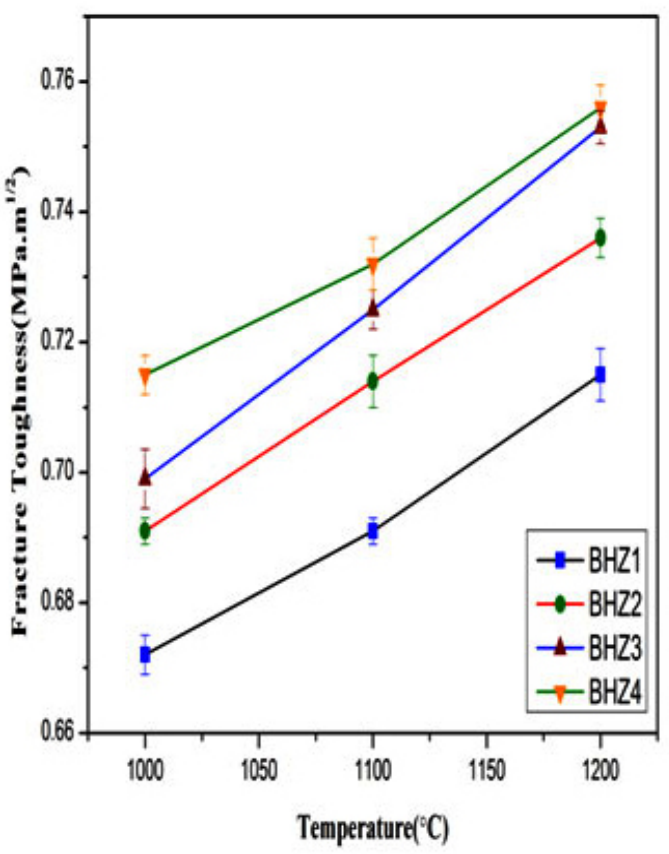

(c)

Fig.6: (a) Density and Vickers microhardness (b) Compressive strength (c) Fracture toughness of biocomposites (BHZ1, BHZ2, BHZ3 and BHZ4) sample 
and hydroxyapatite layer formation on the surface of BHZ samples are shown using (SEMEV018,CarlZeiss,UK) Fig.5(a-d). Before in vitro studies, a compact and uniform morphology is viewed for $\mathrm{BHZ}$ sample. Where $\mathrm{BHZ}$ samples obtained after 21 days of immersion in SBF, clear spherical apatite crystals were seen on the surface, which matches with the measured results ${ }^{48}$. After in vitro studies, due to introduction of hydroxyapatite and $\mathrm{ZrO}_{2}$ in $\mathrm{BHZ}$ sample a strong formation of $\mathrm{HA}$ layer on the sample surface took place. The above results shows that reactivity of $\mathrm{BHZ}$ sample is high in SBF samples. Fig. 5(e-h) shows the cross-sectional view and corresponding energy dispersive (EDS) spectra of $\mathrm{BHZ}$ sample after in vitro studies by using instrument (EDS-51N1000,Oxford,UK). The observed results show an embedded spherical hydroxyapatite layer on the surface of the biocomposite. Calcium and phosphate on the biocomposite surface is confirmed by EDS spectra of BHZ sample, which shows the presence of strong in vitro bioactivity.

\section{Mechanical properties of $\mathrm{BHZ}$ biocomposites}

Fig.6(a) shows the density and micro hardness of biocomposite, this result shows increase in hydroxyapatite and zirconia content which leads to increase in density and hardness value. Fig.6(b) and (c) shows the strength and fracture toughness of $45 \mathrm{~S} 5, \mathrm{BHZ1}, \mathrm{BHZ2}, \mathrm{BHZ3}$ and $\mathrm{BHZ} 4$ samples as a function of sintering temperature and found to increase with increasing sintering temperature. In Fig.6(b) the strength of the 45S5, BHZ1, BHZ2, BHZ3 and $\mathrm{BHZ} 4$ composite samples was about $56 \mathrm{MPa}$, $65 \mathrm{MPa}, 72 \mathrm{MPa}, 88 \mathrm{MPa}, 109 \mathrm{MPa}$ respectively. Sintering at $1000^{\circ} \mathrm{C}$ lowering the strength of the bodies due to insufficient compactness. With increasing sintering temperature to $1200^{\circ} \mathrm{C}$ the strength value increases due to complete compactness. The fracture toughness show significant changes with the changing sintering temperature. The fracture toughness of the samples sintered at $1000^{\circ} \mathrm{C}, 1100^{\circ} \mathrm{C}$ and $1200^{\circ} \mathrm{C}$ were $\mathrm{BHZ1}(0.672,0.691,0.715 \mathrm{MPa}$. $\mathrm{m} 1 / 2), \mathrm{BHZ2}(0.691,0.714,0.736 \mathrm{MPa}$. $\mathrm{m} 1 / 2), \mathrm{BHZ3}(0.699,0.725,0.753 \mathrm{MPa} . \mathrm{m} 1 / 2)$ and $\mathrm{BHZ4}(0.715,0.732,0.756 \mathrm{MPa} . \mathrm{m1} / 2)$ respectively. Therefore, due to its superior strength and toughness, the samples sintered at $1200^{\circ} \mathrm{C}$ were chosen for a set of structural examinations.

\section{CONCLUSION}

The increasing amount of hydroxyapatite $(10,20,30,40 w t \%)$ and zirconia $(5,10,15,20 \mathrm{wt} \%)$ reinforced with base bio active glass upto the limit increase the bioactivity. Beyond $20 \mathrm{wt} \%$, addition of $\mathrm{ZrO}_{2}$ causes a decrease in maxima of the $\mathrm{pH}$ of SBF solution containing immersed samples. Present investigation it was found that bio composite having $40 \mathrm{wt} \% \mathrm{HA}, 20 \mathrm{wt} \% \mathrm{ZrO}_{2}$ and $40 \mathrm{wt} \%$ bioactive glass have highest bioactivity, density, micro hardness, compressive strength and fracture toughness. Thus, we can say that reinforcement of $\mathrm{HA}+\mathrm{ZrO}_{2}$ in the $45 \mathrm{~S} 5$ bioactive glass would be a good bioactive materials.

\section{ACKNOWLEDGMENT}

The authors gratefully thanks to Department of Ceramic Engineering, IIT (BHU) and Central Instrument Fascility, IIT (BHU) Varanasi, India for providing required facilities for the present research work. The present work was supported by Rajiv Gandhi National Fellowship, University Grant Commission, New Delhi, India

\section{REFERENCE}

1. Hench, L.L.; Splinter, R.J.; Allen, W.C.; Greenlee, T.K.; J. Biomed. Mater. Res.1971, 2, 117.

2. Hench, L.L.; Bioceramics: From concept to clinic. J. Am. Ceram Soc.1991, 74,14871510.

3. Cao, W.; Hench, L.L.; Bioactive Materials. Ceramics International 1996, 22, 493-507.

4. Hamadouche, M; Meunier, A.; Greenspan,D.C.;
Blanchat,C.; Zhong, J.P.; Torre, G.P. La; Sedel, L. J. Biomed. Mater. Res. 2001, 54,560.

5. Jarcho, M; Kay, JF; Gumaer, KI; Doremus, RH; Drobeck, HP; Tissue, cellular and subcellular events at a bone-ceramic hydroxylapatite interface. J. Bioeng.1977, 1(2), 79-92.

6. Nayak, AK.; Hydroxyapatite synthesis methodologies: An overview. Int. J. Chem. Tech. Res. 2010, 2(2), 903-7. 
7. Hench, L.L.;Wilson; J. An Introduction to Bioceramics. World Scientific1993, 386.

8. Balani, K; Lahiri, D; Keshri, AK; Bakshi, SR; Tercero, JE; Agarwal, A; The nano-scratch behavior of biocompatible hydroxyapatite reinforced with aluminum oxide and carbon nanotubes. Jom 2009, 61(9), 63-6.

9. Sollazzo, V; Pezzetti, F; Scarano, A; Piattelli, A; Bignozzi, CA; Massari, L; Zirconium oxide coating improves implant osseo integration in vivo. Dent Mater 2008, 24, 357-61.

10. Albrektsson, T; Hansson, HA; Ivarsson, B; Interface analysis of titanium and zirconium bone implants. Biomaterials 1985,6, 97-101.

11. Masonis, JL; Bourne, RB; Ries, MD; McCalden, RW; Salehi, A; Kelman, DC; Zirconia femoral head fractures: a clinical and retrieval analysis. J. Arthroplast 2004, 19, 898-905.

12. DeAza, AH; Chevalier, J; Fantozzi, G; Schehl, M; Torrecillas, R; Crack growth resistance of alumina, zirconia and zirconia toughened alumina ceramics for joint prostheses. Biomaterials 2001, 23, 937-45.

13. Kong, Y; Yang, Z; Zhang, G; Yuan, Q; Friction and wear characteristics of mullite, ZTM and TZP ceramics. Wear 1998, 218,159-66.

14. Kohal, RJ; Wolkewitz, M; Mueller, C; Aluminareinforced zirconia implants: survival rate and fracture strength in a masticatory simulation trial. Clin. Oral Implants Res. 2010 ,21, 1345-52.

15. Atilgan, S; Erol, B; Yardimeden, A; Yaman, F; Ucan, MC; Gunes, N; A three dimensional analysis of reconstruction plates used in different mandibular defects. BiotechnolBiotechnol Equip.2010,24, 1893-6.

16. Nisitani, H; Kim, YH; Goto, H; Nishitani, H; Effects of gage length and stress concentration on the compressive strength of a unidirectional CFRP. EngFractMech 1994, 49, 953-61.

17. Li, J; Liao, H; Hermansson, L; Sintering of partially-stabilized zirconia and partiallystabilized zirconia-hydroxyapatite composites by hot isostatic pressing and pressureless sintering. Biomaterials 1996, 17(18), 1787-90.

18. Silva, V V.; Lameiras, FS; Domingues, RZ; Microstructural and mechanical study of zirconia-hydroxyapatite $(\mathrm{ZH})$ composite ceramics for biomedical applications. Compos .Sci.Technol. 2001 ,61, 301-10.

19. Delgado, JA; Morejo'n, L; Marti'nez, S; Ginebra, MP; Carlsson, N; Ferna'ndez, E; Zirconia-toughened hydroxyapatite ceramic obtained by wet sintering. J. Mater Sci. Mater Med. 1999, 10(12), 715-9.

20. Kong, Y-M; Kim, S; Kim, H-E; Lee, I-S.; Reinforcement of Hydroxyapatite Bioceramic by Addition of $\mathrm{ZrO} 2$ Coated with $\mathrm{Al} 2 \mathrm{O} 3$. J. Am. Ceram Soc. 2004, 82(11), 2963-8.

21. Takagi, M; Mochida, M; Uchida, N; Saito, $\mathrm{K}$; Uematsu, K.; Filter cake forming and hot isostatic pressing for TZP-dispersed hydroxyapatite composite. J. Mater Sci. Mater Med. 1992 ,3(3),199-203.

22. Li, J; Hermansson, L; Söremark, R; Highstrength biofunctional zirconia: mechanical properties and static fatigue behaviour of zirconia-apatite composites. J. Mater Sci. Mater Med. 1993 ,4(1),50-54.

23. Zhang, J; Iwasa, M; Kotobuki, N; Tanaka, $\mathrm{T}$; Hirose, M; Ohgushi, $\mathrm{H}$; Fabrication of Hydroxyapatite Zirconia Composites for Orthopedic Applications. J. Am. Ceram Soc. $2006,89(11), 3348-55$.

24. Khalil, KA; Kim, SW; Kim, HY; Consolidation and mechanical properties of nanostructured hydroxyapatite( $\mathrm{ZrO} 2+3 \mathrm{~mol} \%$ Y2O3) bioceramics by high-frequency induction heat sintering. Mater Sci. Eng. A. 2007 ,456(1-2), 368-72.

25. Rapacz-Kmita, A; lósarczyk, A; Paszkiewicz, $\mathrm{Z}$; Mechanical properties of $\mathrm{HAp}-\mathrm{ZrO}_{2}$ composites. J Eur Ceram Soc. 2006, 26(8), 1481-89.

26. Wu; Jenn-Ming; T-SY; Sintering of hydroxylapatite-zirconia composite materials. J. Mater Sci. 1988, 23(10),3771-78.

27. Little flower ,G; Reddy ,M. Srinivasa; Reddy ,M.V. Ramana; Veeraiah, N.; Naturforsch ,Z.; A: Phys. Sci. 2007, 62, 315.

28. Reddy,M. Srinivasa ; NagaRaju ,G.; Nagarjuna,G.; Veeraiah, N. ; J. Alloys Comp. 2007,41, 438.

29. Ghosh, S. ; Sharma, A.; Talukder, G.; Biol. Trace Elem. Res.1992, 35, 247.

30. Vallet-Regi, M; González-Calbet, J.M.; Calcium phosphates as substitution of bone 
tissues. Prog. Solid State Chem. 2004, 32, $1-31$.

31. Shen, Z.J.; Adolfsson, E.; Nygren, M.; Gao, L.; Kawaoka, H.; Niihara, K.; Densehydroxyapatite-zirconia ceramic composites with high strength for biological applications. Adv.Mater. 2001, 13, 214-216.

32. Silva,V.V.; Domingues, R.Z.; Lameiras, F.S.; Microstructural and mechanical study of zirconia-hydroxyapatite $(\mathrm{ZH})$ composite ceramics for biomedical applications. Compos. Sci. Technol. 2001, 61, 301-310.

33. Zhang, C.; Zhang, X.; Liu, C.; Sun, K.; Yuan, J.; Nano-alumina/hydroxyapatite composite powders prepared by in-situchemical precipitation. Ceram.Int. 2016, 42, 279-285.

34. Milella, E.; Cosentino, F.; Licciulli, A.; Massaro, C.; Preparation and characterisation of titania/ hydroxyapatite composite coatings obtained by sol-gel process. Biomaterials 2001, 22, 1425-1431.

35. Parente, P.; Sanchez-Herencia, A.J.; MesaGalan, M.J.; Ferrari, B.; Functionalizing TiSurfaces through the EPD of hydroxyapatite/ nanoY2O3. J.Phys.Chem., 2012, B 117,16001607.

36. Kokubo, T; Kushitani, H; Sakka, S;Kitsuqi,T; Yamamuro, T.; Solutions able to reproduce in vivo surface-structure changes in bioactive glass-ceramics A-W. Journal of Biomedical Materials Research 1990, 24, 721-734.

37. Tampieri, A.; D'Alessandro,T.; Sandri,M.; Sprio,S.; Landi,E.; Bertinetti,L.; Panseri,S.; Pepponi, G.; Goettlicher,J.; BañobreLópez, M.; Rivas, J.; Intrinsic magnetism and hyperthermia in bioactive Fe-doped hydroxyapatite. ActaBiomater. 2012, 8 (2), 843-851.

38. Fujibayashi, S.; Neo, M.; Kim, H.M.; Kokubo, T. ; Nakamura, T.; A comparative study between in vivo bone in growth and in vitro apatite formation on Na2O-CaO-SiO2 glasses. Biomaterials 2003, 24, 1349-1356.
39. Clupper, D.C.; Gough, J.E.; Embanga, P.M.; Notingher,I.; Hench, L.L.; Hall ,M.; Bioactive evaluation of $45 S 5$ bioactive glass fibres and preliminary study of human osteoblast attachment. J. Mater. Sci. Mater. Med. 2004, 15, 803-808.

40. Kokubo, T.; Surface chemistry of bioactive glass-ceramics. J. Non-Cryst. Solids 1990, 120,138-151.

41. Kim, H.; Miyaji, F.; Kokubo, T.; Kokubo (1995). Bioactivity of $\mathrm{Na}_{2} \mathrm{O}-\mathrm{CaO}-\mathrm{SiO}_{2}$ glasses. J. Am. Ceram. Soc. 1995, 79 (9), 2405-2411.

42. Wu, J.M.;Yeh, T.S.; Sintering of hydroxylapatitezirconia composite materials. J. Mater. Sci.1988 , 23, 3771.

43. Barbieri, L.; Cannillo, V.; Leonelli, C.; Montorsi, M.; Mustarelli, P.; Siligardi, C.; Experimental and $\mathrm{MD}$ simulations study of $\mathrm{CaO}-\mathrm{ZrO}_{2}-$ $\mathrm{SiO}_{2}$ glasses. J.Phys.Chem.B 2003, 107, 6519-6525.

44. Greenspa, DC; L.L. Hench; Chemical and mechanical behavior of bioglass coated alumina. J. Biomed Materials Res. 1976, 10, 503-509.

45. Satoshi, H; Kanji, T; Chikara, O; Akiyoshi, O; Mechanism of Apatite Formation on a Sodium Silicate Glass in a Simulated Body Fluid. $J$. Am Ceram Soc. 1999, 82, 2155-2160.

46. Toshihiro, K; Yoshimasa, H; Masayuki, N; Mitsuo, N; Apatite Formation on Calcium Phosphate Invert Glasses in Simulated Body Fluid. J. Am Ceram Soc. 2001 , 84, 450-452.

47. Clark, AE; Pantano, CG; Hench, L.L.; Auger spectroscopic analysis of Bioglass corrosion films. J. Am Ceram Soc.1976, 59, 37-39.

48. P.Li, Ohtuki, C.; Kokubo, T.; Nakanishi, K.; Soga, N.; Nakamura, T.; Yamamuro, T.; Effects of ions in aqueous media on hydroxyapatite induction by silica gel and its relevance to bioactivity of bioactive glasses and glassceramics. J. Appl. Biomater. 1993, 4, 221229. 